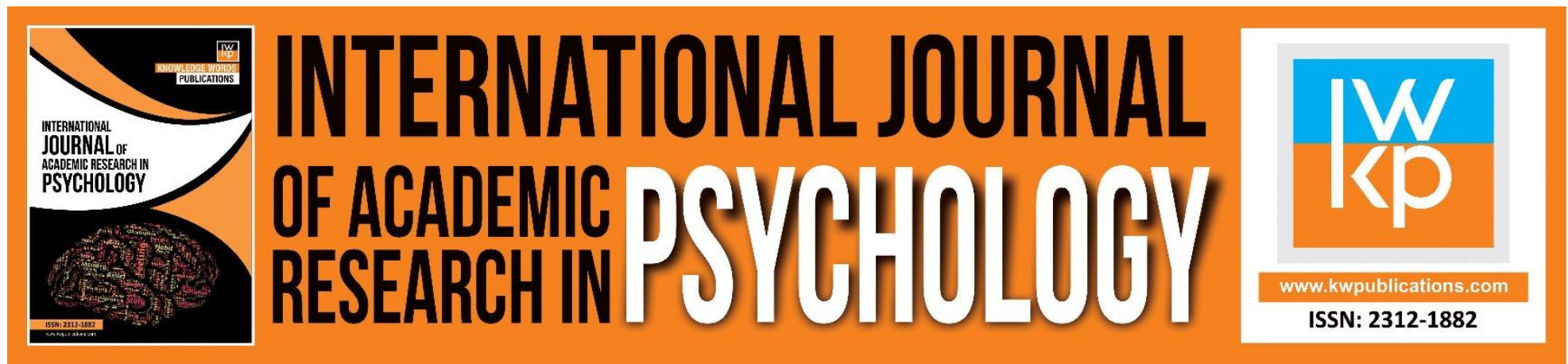

\title{
The Coping Strategies among Student-Athletes who have to Let Go their Academic Goal
}

\author{
M.S. Omar-Fauzee, Yahya Don, Yaakob Daud, Muhamadul Bakir Yaakub, \\ Nina Sutresna, Nagoor Meera Abdullah
}

To Link this Article: http://dx.doi.org/10.46886/IJARP/v1-i1/914

DOI:10.46886/IJARP/v1-i1/914

Received: 03 September 2014, Revised: 11 November 2014, Accepted: 12 December 2014

Published Online: 24 December 2014

In-Text Citation: (Omar-Fauzee et al., 2014)

To Cite this Article: Omar-Fauzee, M. S., Don, Y., Daud, Y., Yaakub, M. B., Sutresna, N., \& Abdullah, N. M. (2014). The Coping Strategies among Student-Athletes who have to Let Go their Academic Goal. International Journal of Academic Research in Psychology, 1(1), 43-53.

Copyright: () 2014 The Author(s)

Published by Knowledge Words Publications (www.kwpublications.com)

This article is published under the Creative Commons Attribution (CC BY 4.0) license. Anyone may reproduce, distribute, translate and create derivative works of this article (for both commercial and non-commercial purposes), subject to full attribution to the original publication and authors. The full terms of this license may be seen

at: http://creativecommons.org/licences/by/4.0/legalcode

Vol. 1, No. 1, 2014, Pg. 43 - 53

https://kwpublications.com/journals/journaldetail/IJARP

JOURNAL HOMEPAGE

Full Terms \& Conditions of access and use can be found at https://kwpublications.com/pages/detail/publication-ethics 


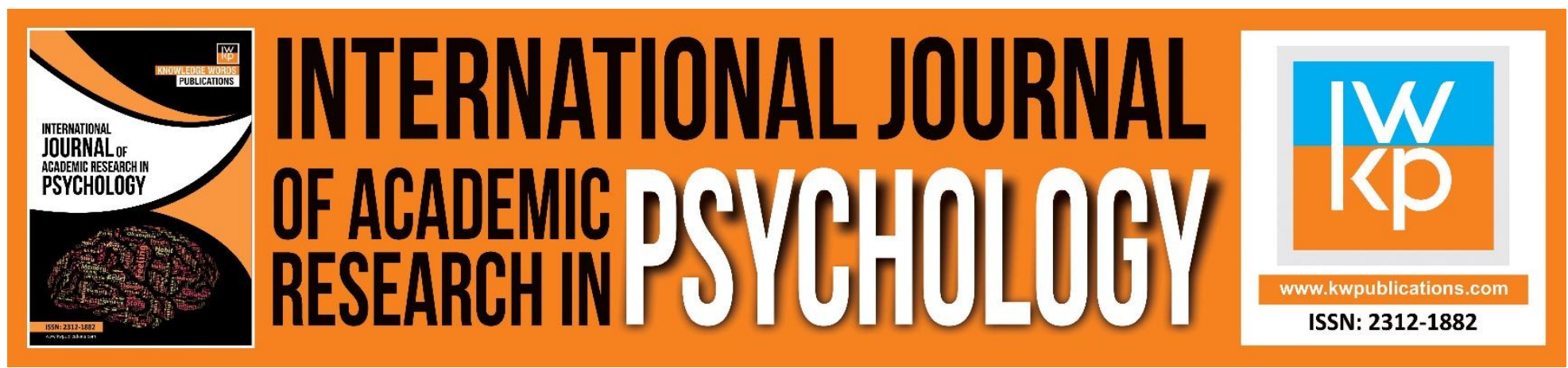

\title{
The Coping Strategies among Student-Athletes who have to Let Go their Academic Goal
}

\author{
M.S. Omar-Fauzee, Yahya Don, Yaakob Daud \\ Universiti Utara Malaysia
}

Muhamadul Bakir Yaakub

Universiti Islam Antarabangsa Malaysia

Nina Sutresna

Univeristi Pendidikan Indonesia

Nagoor Meera Abdullah

Universiti Teknologi MARA

\begin{abstract}
The main purpose of this study was to examine the relationship of the coping strategy and level of representations of student-athletes at university level. More specifically, it also investigates the relationship of high school level of sport representations and university level of sport representation. A sample of 307 (female-213; male-94) university students-athletes in one of the public university in Malaysia were randomly selected for this study. The age of the student-athletes $(M=22.09, s d=1.35$ Out of the number, 210 represented college dormitory, 51 represented university at National level, and 46 represented state at national level, and 6 representing Nation at International level. The Athletic Coping Skills Inventory - 28 was used to measure the psychological coping skills for athletes. The instrument consisted of a 28-item scale measuring seven classes of sport-specific psychological coping skills including confidence, goal setting, coping with adversity, freedom from worry, coachability, concentration, peaking under pressure, and goal setting. Results shows that all of the seven coping strategies were significantly correlated with the four level of university representations. The major findings found that a high correlation between the goal setting and confidence level of the athletes. Another findings also found that the goal setting and confidence level also moderately correlated with coping with adversity. However, a weak relationship was found between high chool sports representation and university level of sports representations. Results were further discussed and suggestions for future research also suggested in this paper.
\end{abstract}


INTERNATIONAL JOURNAL OF ACADEMIC RESEARCH IN PSYCHOLOGY

Vol. 1, No. 1, 2014, E-ISSN: 2312-1882 @ 2014 KWP

Keywords: Coping Strategy, University Student-athletes, Coping with Adversity, Confidence and Goal Setting.

\section{Introduction}

The ability of using psychological skills has major impact on athletes to perform at their best because it allow athletes to deal with pressure, distractions, and adversity that can lower their capacity to performance (Clough \& Strycharczyk, 2012; Omar-Fauzee et al., 2013). Thus, no matter how well one had trained themselves during practice, they still have a tendency to think of threat and afraid of losing which later on will make them losing their focus and perhaps will make them feel unsecure of their ability (Dalkhoter, 2008). Likewise, Gould, Dieffenbach, and Moffet (2002) also identify that successful Olympian required high mental strengh which nurture them to perform better in stressful competitive surroundings. Thus, it is sport psychologist duty to help those who unable to control their emotions or unable to focus during the game to become more stable indeed (Weinberg \& Gould, 2011). Relatively, sport psychologist should work hand-in-hand with coaches and athletes to assure that what athletes have practiced during training really transpire during the competition (Ferrante, Etzel, \& Lantz, 2002). As for those developed countries that understand the needs of sport psychologist for the team, it should not be so hassle, however for developing countries which still have so many ignorant coaches about the benefit of the sports psychologist is then a fuss. Therefore, no matter what the situation is, the sport researchers should conduct more research to ensure that coaches will understood the important of psychological tools in training and competition. Thus, the study on Malaysian student-athletes is a positive step toward acknowledging the needs of psychologicall skills for athletes (Omar-Fauzee, et al., 2013).

According to Sheard (2010) athletes should learned and be taught the process of mental toughness and coping strategy in order to assure that their competency can sustain at appropriate level, especially when compete at International level. At the elite competition, athletes may have same physical capabilities, same level of strategy, and high level of technical ability, but only with slight mistake of mental attention it can create a distrousness situation for the individu (Hoggs, 2002; Moran, 2007). Therefore, high level of mental strength training to cope themselves in stressful situation will enable them to be world class athletes. Therefore, it is a need that athletes learned and trained themselves with sports psychologist on how to perform themselves (Connaughton, Hanton \& Johns, 2009). This intention should be started at early stage before they becoming world class athletes. Perhaps, by investigating the university student-athletes on coping strategies is the right move towards developing a great athletes.

Futrthermore, study by Omar-Fauzee, et al., (2014b) found that the main problems with studentathletes are nervous before games, avoiding injury, spectators disruptions, and personal problems. All of this stressful conditions, perhaps due to lack of readiness to cope with the unforseen circumstances that they might faced. Thus, unable to cope these competititive pressure before the game will conceive them to perform poorly, incapable to study the game, and unable them to change strategy in a split-second (Omar-Fauzee, Daud, Abdullah, \& Rashid, 2009). In any competition, athletes also have to bare in mind that they also have to confront and cope with losing. On the other hand, Omar-Fauzee, Abd-Latif, Tajularipin, Manja and Rattanakoses (2011) found that athletes who lost their game also quest for social support and psychological skills to cope with their emotional frustration. Therefore, the usage of psychological skills including coping strategy of winning or losing, 
concentration, goal setting, imagery, and self-confidence will helps to raise their motivation in order to maintain their peak performances (Rattanakoses, Omar-Fauzee \& Soh, 2009). These emotional and psychological monitoring were critically required, especially when athletes are in a condition where they feel unsecure, threaten, fearful, nervous, and uptight to perform at their best (Dominikus, Omar-Fauzee, Abdullah, Meesin \& Choosakul, 2009). Moreover, student-athletes who are prepared and equipped themselves with coping strategies and mental toughness are more complacent to perform, qualify and confidence to compete (Loehr, 1986; Moran, 2007; Omar-Fauzee et al., 2010). In the case of the university student-athletes, they are also confronted with workload of academic demands that one has to fullfil which includes attending classes and labs, prepare themselves with project papers and assignments, and of course passing the examination (Ferrante, et. al., 2002; Hickey \& Kelly, 2005). The balancing both the sports performance and academic achievements are difficult task that student-athletes have to confront. Consequently, Cosh and Tully (2014) research on Australian student-athlets also revealed that the essential academic goal for student athletes is all I have to do is just pass. In other words, they have to sacrifice their educational success in order to integrate both sports and academics. Thus, this academic pursuit for excellence had made them more stressful to face the sports competition. To overcome it, some have to let go the academic pressure while competing. More flatten, they also have to overcome the competition pressure like other elite athletes in order to success in their games. Thus, student-athletes who are carry two big responsibilities (i.e., academic pursuit and sporting competence) should also trained themselves on how to cope with these stressful situation (Jobling \& Boag, 2003). Consequently, this study will examine the realationship of coping strategy of student-athletes and their level of representation during their study at the university. This is important because the findings will help coaches and athletes to strategise their training program (Omar-Fauzee, et al., 2012; Omar-Fauzee, 2014a).

\section{Methodology}

\section{Sample}

A sample of 307 (male-94; female-213) university students-athletes in one of the public university in Malaysia were randomly selected for this study. The age of the student-athletes $(M=22.09, \mathrm{sd}=1.35)$. Out of 310 respondents, 210 represented college dormitory, 51 represented university at National level, and 40 represented state at national level, and 6 representing Nation at International level. They are involved in both the team and individual sports representing a wide variety of sports (i.e. swimming, badminton, netball, softball, rugby, track and field, bowling, soccer, futsal, volleyball and field hockey).

\section{Instrumentation}

The questionnaire was divided into two parts, namely: demographic variables; and the athletic coping skills inventory -28 .

\section{Demographic Variables}

The questionnaire also contained items that identified the gender, age, race, and level of sports participation during high school, level of sports representation in the university. 
INTERNATIONAL JOURNAL OF ACADEMIC RESEARCH IN PSYCHOLOGY

Vol. 1, No. 1, 2014, E-ISSN: 2312-1882 @ 2014 KWP

\section{Athletic Coping Skills Inventory - 28}

In this study, the Athletic Coping Skills Inventory - 28 (ACSI-28; Smith, Schultz, Smoll, \& Ptacek, 1995) was used to measure the psychological coping skills for athletes. The instrument consisted of a 28item scale which tend to measure seven coping skills of sport-specific which includes concentration, peaking under pressure, confidence, freedom from worry, coping with adversity, goal setting, and coachability. The respondents were asked to respond to each statement by indicating how often they experienced different situations using a 4 point Likert-like scale $(0=$ almost never to $3=$ almost always). Example for goal setting skill; On a daily or weekly basis I set very specific goals for myself that guide what I do. Each The scales were then summed to yield a personal coping resource score. The internal reliability as reported by original authors, Smith, Schutz, Smoll and Ptacek (1995) were found to be internally consistent with alpha croncbach levels ranging from .62 to .78 and a total (personal coping resources) scale alpha of .86.

Figure 1: Terms and definitions of ACSI - 28 psychological coping skills

Sub-scales Descriptions and example of question

Freedom from Worry Does not put pressure on him/herself by worrying

about performing poorly or making mistakes; does

not worry about what others will think if he/she

performs poorly.

(I worry quite a bit about what others will think

Coping with Adversity about my performance*)

Remains positive and enthusiastic even when things

are going badly; remains calm and controlled; can

quickly bounce back from mistakes and setbacks.

(I remain positive and enthusiastic during

competition, no matter how badly things are going)

Peaking Under

Pressure

Is challenged rather than threatened by pressure

situations and performs well under pressure; a clutch

performer.

(I tend to perform better under pressure because I

think more clearly)

Goal Setting

Sets and works towards specific performance goals;

plans and mentally prepares him/herself for

competition and clearly has a 'game plan' for the competition.

(I tend to do lots of planning about how to reach my goals)

Concentration Not easily distracted; able to focus on the task at hand in both practice and competitive situations, even when adverse or unexpected events occur. (It is easy for me to direct my attention and focus on a single object or person) 
INTERNATIONAL JOURNAL OF ACADEMIC RESEARCH IN PSYCHOLOGY

Vol. 1, No. 1, 2014, E-ISSN: 2312-1882 @ 2014 KWP

Confidence Is confident and positively motivated; consistently

gives $100 \%$ during practice and competitions and

works hard to improve his/her skills.

(I feel confident that I will perform well)

Coachability

Open to and learns from instruction; accepts

constructive criticism without taking it personally or

becoming upset.

(If a coach criticizes or yells at me I correct the

mistake without getting upset about it)

Notes: *Reverse marks

Source: Adapted from Smith, R. E., \& Christensen, D. S. (1995). Psychological skills as predictors of performance and survival in professional baseball. Journal of Sport and Exercise Psychology, $17,399-415$.

\section{Procedure}

The permission was asked from the Director of Sports Center of the university involved before conducting this research. Once approved, the researcher with the help of coaches and student leaders of the specific sports conducting the research at the playing field and courts. The respondents was briefly explained of the objective of the research and they were also notify that they can quit at anytime during the answering session if they feel uncomfortable. It took approximately 25 minutes to answer the Malay translated questionnaire. This Malay translation was validated by English expert from the first author university. The completed set of questionnaire answered was immediately collected after the respondents satisfied with their answered.

\section{Analysis of Data}

All the data were analyzed using the Statistical Package of Social Sciences (SPSS) program software version 19.0. The objective of this study is to examine the relationship of coping strategy of studentathletes and their level of representations during their study at the university. The discriptive statistic (Mean and standard deviation) was employed to identified the demographic of the respondents. In addition, the pearson correlation measurement was used to examine the significant relationship among the level of participation and coping strategies of stident-athletes.

\section{Results}

Result obtained from the study shows that out the 307 respondents; 213 are male and 94 female student-athletes. They are divided into 210 students representing at college level, 51 representing university at national level, 40 representing state at National level, and only 6 representing Nation at International level. There are races/ethnic who participate in this study that are; 217 Malays, 42 Chinese, 39 Indian, and 9 others. The mean age of the respondents are $(M=22.09$, $\mathrm{sd}=1.35$ ). All of the coping strategies have the internal reliability between $.65-.80$ which is appropriate. On the other hand, those who represented National team (6) at International level, do representing state (1) and Nation (5) during their high school (Table 1). However, most studentathlete who representing state (43) and Nation (7) during high school only did participate at college 
level only. The relationship between high school and university level of participations show significantly correlated $(r=.28, p<.05)$, but with a weak relationship.

Results also show that the correlation between the level of participation among university student-athletes and coping strategies are significantly correlated with each other. The confident $(r=.29, p<.05)$, goal setting $(r=.33, p<.05)$ and freedom from worry $(r=.39, p<.05)$ show slightly poor significant. However, coping with adversity $(r=.42, p<.05)$, peaking under pressure $(r=.48, p<.05)$, and concentration $(r=.41, p<.05)$ showed middle correlation, and coachability $(r=.55, p<.05)$ was the highest correlation among them (Table 2).

Table 1. Sports representations during high school

\begin{tabular}{lccccccc}
\hline & 1 & 2 & 3 & 4 & 5 & Total \\
\hline Representing College & 24 & 32 & 104 & 43 & 7 & 210 \\
Representing University/state level & 2 & 8 & 23 & 16 & 2 & 51 \\
Representing Malaysian University & 0 & 2 & 21 & 17 & 0 & 40 \\
Representing Nation at International & 0 & 0 & 0 & 1 & 5 & 6 \\
\hline
\end{tabular}

Notes: 1. Representing house at school level, 2. Representing school at district level, 3. Reresenting district at state level, 4. Representing state at national level, and 5. Representing Nation at International level.

Figure 2. Sports Representative during high school and university

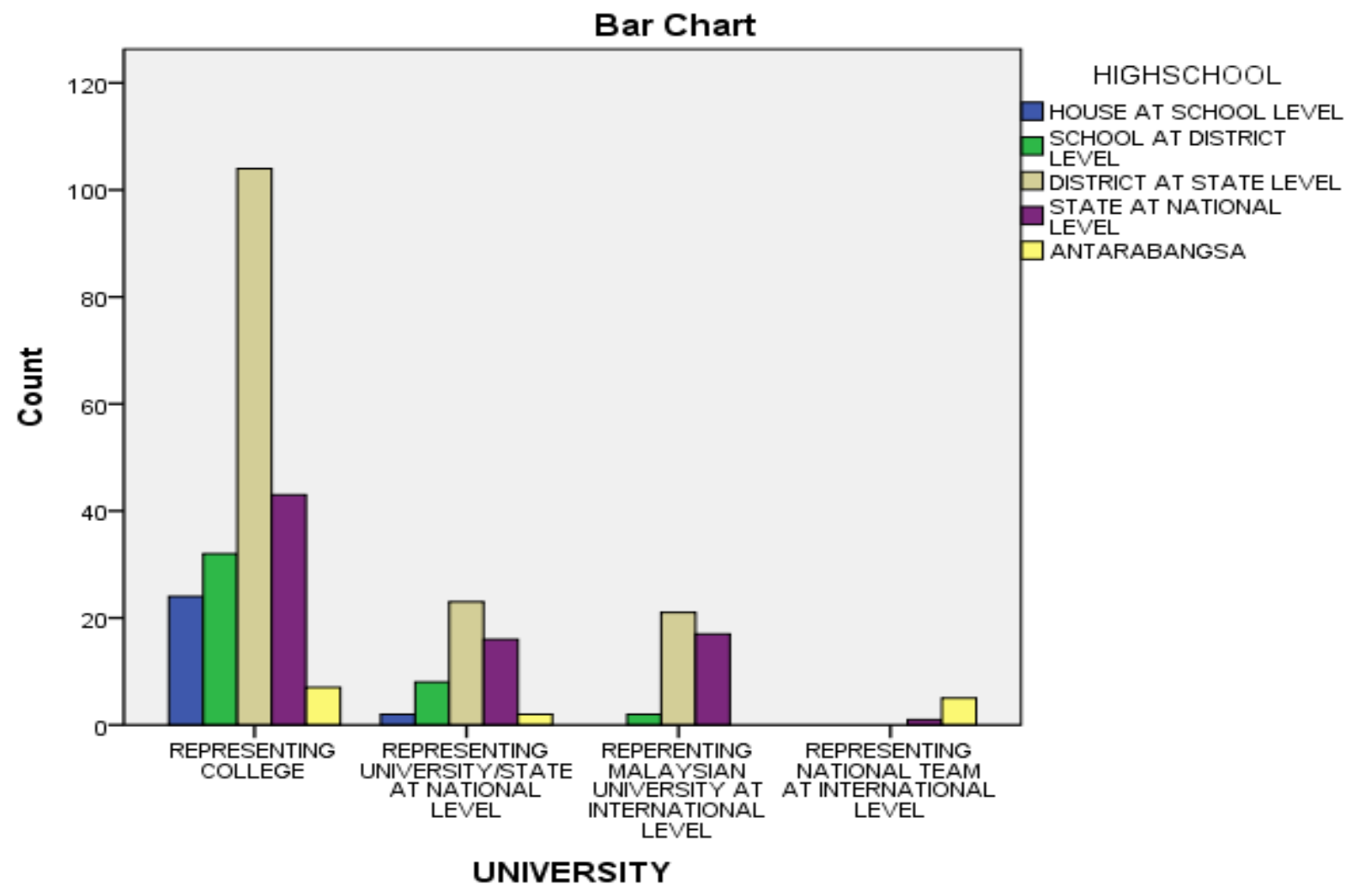


INTERNATIONAL JOURNAL OF ACADEMIC RESEARCH IN PSYCHOLOGY

Vol. 1, No. 1, 2014, E-ISSN: 2312-1882 @ 2014 KWP

Table 2: The Correlations of level of University Representations and the Coping Strategies among the Student-athletes.

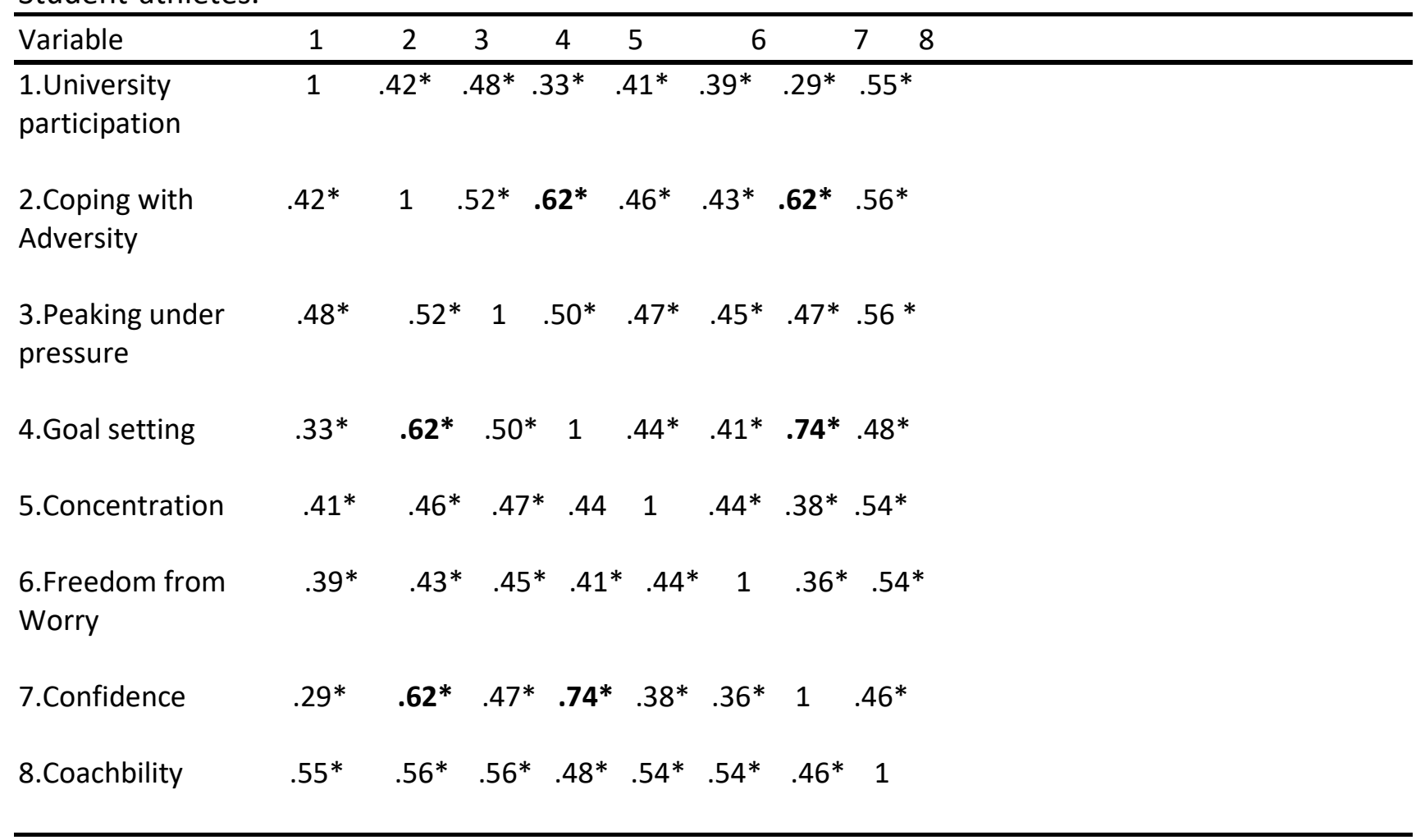

Notes: ${ }^{*} p<.05$

1. representing at college level, 2. representing university at national level, 3.representing state at National level, and 4. representing Nation at International level.

\section{Conclusion}

The purpose of this paper is to examine the relationship between the level of representations and coping strategy employed by student-athletes at a particular public university in Malaysia. In order to understand their high school sport behavior, this study had also examined the relationship between their high school representations in sports as compare to their recent representation at the university as student-athletes. Results show that there are a weak correlation between high school sports representation and university representation. Additionally, it has identify that only those who represented high school at state and National level will continuously representing Nation during their university year. This shows that their interest to pursue their intention for participation in sports during university was still deep and they continuously expand their behavior even at university level. Those who have experienced playing during their adolescent also show better mental training skills in their recent sports (Sadeghi et al., 2010). Moreover, those who representing sports at higher level during high school, display lower anxiety level as compare to those who don't (Omar-Fauzee et al., 2008). However, further study should be conducted because it is curious to find out that half of student-athletes who used to representing National team during high school only representing college level in the university. Is it because of academic pressure or their inability to cope with the sport program? Or perhaps, is it because they have change interest? Perhaps, study by Cosh and 
Tully (2014) was to be considered where they found that most student-athletes declining themselves in taking part at higher level. Cosh and Tully identified that one of the main reasons that potential student-athletes quitting from sports participation are unable to cope with the tendency of failure in completing their tertiary education.

However, this study also found that the trend of participating sports at university was still due to their high school interest, whereby high number of student-athletes who used to represented state and district level are continuously representing university and Malaysian University team. Thus, this shows that those who used to be active during adolescent will keep on doing it after finishing schools. Perhaps, due to the good facilities of sports and well managed sports program at university level have made them interest to keep on active even with academic pressure (Omar-Fauzee, Yusof, \& Zizzi, 2009). On the other hand, the more involvement the athletes were, the more capable they can cope with the psychological threat that causing encumbrance to compete (Crust \& Azadi, 2010). Moreover, Sheard (2010) also suggested that the experience individual were more confidence and more focus when compete in a game. However, the reason of why those who only representing house level at high school were still remain participating at lower level of representation need also to be examined in order to understand their participatory behavior.

It is interesting to find out that there are good correlation between the goal setting and confidence level student-athletes. This shows that the better the goal setting created by the studentathletes the more confidence they were. Perhaps, the attitude of setting up their daily or weekly basis such as 'On a daily or weekly basis I set very specific goals for myself that guide what I do' had been able to improve their confidence level because they are well planned and know what to do (Moran, 2007). In other words, with daily goal-setting log it will guide the individual to be more focus on the task that they have to deliver. Therefore, the student-athletes should developed a proper goal-setting diary in order to improve their confident level in sports. According to Omar-Fauzee et al., (2013) apart of being positive, goal setting is another major contributions toward mental toughness among athletes that need to be focused by athletes. Furthermore, with proper planning of what to do next will help the athlete to identify the needs they should do next (Hogg, 2002; Weinberg \& Gould, 2011). By proper and regular planning, it will also helps athletes to forsee the future problems and thus, it will improve their confidence level because they are ready to face whatever circumstances (Dahlkoetter, 2008). Therefore, this findings also suggest that studentathletes should learned on how to create the log or diary of goal setting to fulfil their psychological needs in order to perform in sports (Kada et al., 2011).

Another interesting finding is that the confidence and goal setting also have moderately high correlation with coping with adversity. Thus, the study shows that if the individual athlete has high confidence and goal setting their ability to cope with adversity is higher. Therefore, the resilence program as suggested by Omar-Fauzee et al., (2014b) seem to be in the same direction with the findings. Thus, it shows that no matter how worst the catastrope is to the athletes during game, it can be conquered by the athletes if they have higher confidence level as well as exceptional goals (Omar-Fauzee et al., 2009). Both of these psychological skills did not appear suddenly, but it has to be learned and trained properly in order to helps athlete improve their performances. Thus, sports psychologist should involved with the team in helping athletes to perform at their best without distractions (Omar-Fauzee, et al., 2012). Perhaps, more research on culture based circumstances 
should be introduced to Malaysian and Asian student-athletes so that their capability of maintaining higher performances sustained at International level (Omar-Fauzee, et al., 2013).

Additionally, this study also has its limitations that should be attained. The first limitation is that the research is only focus to a particular university in Malaysia and cannot be generalized entirely with other university student-athletes. Therefore, more research should be conducted to more universities for better understanding of this special group of people who have to "let go their academic goals' in order to fulfill their sporting needs. Perhaps, a specific 'coping strategy inventory' that focused only on student-athletes should be created in the future. Furthermore, a longitudinal study over a period of one year involving only the student-athletes should also be considered. This suggestion is also considering the proposition made by Omar-Fauzee, et. al., (2012) who have suggested that more research on Asian athletes should be conducted in order to help them to improve their coping ability when dealing with stressful competitive environment. In addition, the Asian athletes also should be exposed to psychological skills by sports psychologist in order to create a better mental toughness among them.

\section{References}

Connaughton, D., Hanton, S., \& Jones, G. (2010). The development and maintenance of mental toughness in the world's best performers. The sport Psychologist, 24, 168-193.

Clough, P., \& Strycharczyk, D. (2012). Applied mental toughness: A tool kit for the 21st century. London: Kogan Page.

Cosh, S., \& Tully, P. J. (2014). All I have to do is pass": A discursive analysis of student athletes' talk about priortising sport to detriment of education to overcome stressors and encountered in combining elite sport and tertiary education. Psychology of Sport and Exercise, 15, 180-189.

Crust, L., \& Azadi, K. (2010). Mental toughness and athletes' use of psychological strategies. European Journal of Sport Science, 10, 43-51.

Dahlkoetter, J. (2008). Your performance edge. San Carlos, CA: Pulgas Ridge Press.

Dominikus, F., Fauzee, O. M. S., Abdullah, M. C., Meesin, C., \& Choosakul, C. (2009). Relationship between mental skill and anxiety interpretation in secondary school hockey athletes. European Journal of Social Sciences, 9(4), 651-658.

Ferrante, A. P., Etzel, E., \& Lantz, C. (2002). Counseling college student-athletes: The problem, the need 1996. In E. F. Etzel, A. P. Ferrante, \& J. W. Pinkney (Eds.). Counseling college student-athletes: Issues and interventions (pp 5-26). Morgantown, WV: Fitness Information Technology, Inc.

Gould, D., Dieffenbach, K., \& Moffett, A. (2002). Psychological characteristics and their development in Olympic champions. Journal of Applied sport Psychology, 14, 172-204.

Hickey, C., \& Kelly, P. (2005). Professional education and training for early carrear players in Australian football league: Footy first, second and third. In AARE 2005 conference proceeding (pp 1-13).

Hogg, J. M. (2002). The application of psychological skills to sport and physical activity. Alberta, Canada: Sport Excel Publishing.

Jobling, I., \& Boag, A. (2003). Review of higher education opportunities for elite athletes. Report for National Career and Education program. 
Kada, L. A., Omar-Fauzee, M.S., Pilus, A. H. M., Mohamed, A. M. D. (2011). Penetapan matlamat perangsang kecemerlangan sukan [Goal setting influence the sports excellence]. In M. N. H. Nazarrudin, M.S. Omar-Fauzee, \& Z. Muhamed (Eds). Kekuatan mental dalam sukan [Mental strength in sports] (pp 14-30), Sabah, Malaysia: Universiti Malaysia Sabah Press.

Loehr, J. E. (1986). Mental toughness training for sports: Achieving athletic excellence. Lexington, MA: Stephen Greene Press.

Moran, A. P. (2007). Sport and exercise psychology.London: Routledge.

Omar-Fauzee, M. S., Abd-Latif, R., Tajularipin, S., Manja, R., \& Rattanakoses, R. (2011). The coping strategies employed by female college athletes after losing a game. International Journal of Psychological Studies, 3, 50-57.

Omar-Fauzee, M. S., Chansem, W., Rattanakoses, R., Nazaruddin, M. N., Abdullah, N. M., Parnabas, V., \& Rosli, M. H. (2013). Mental toughness concept for South East Asia athletes. International Journal of Academic Research in Business and Social Sciences, 3(2), 270-278.

Omar-Fauzee, M. S., Daud, W. R. B., Abdullah, R., \& Rashid, S. (2009) A. The effectiveness of imagery and coping strategies in sport performance. European Journal of Social Sciences, 9(1), 97-108, 2009.

Omar-Fauzee, M. S., Don, Y., Samad, N., Abdullah, N. M., Parnabas, V., Nazaruddin, M. N., \& Geok, S. K. (2014a). The student-athletes coping strategy and sources of stress. International Journal of Physical and Social Sciences, 4 (3), 386-405.

Omar-Fauzee, M. S., Don, Y., Sustresna, N., Saputra, Y. M., Hanif, S., Abdullah, N. M., \& Shahril, M.I. (2014b). Examining the Indonesia and Malaysia student-athletes coping strategy in sports. European Scientific Journal (Special Issue), 2, XXX.

Omar-Fauzee, M. S., Lai, W. W., Soh, K. G., \& Latif, R. A. (2008). Sport anxiety among high school athletes. Journal of Physical Education (Hong Kong), 14, 44-48.

Omar-Fauzee, M. S., Saputra, Y. M., Samad, N., Gheimi, Z., Asmuni, M. N., \& Johar, M. (2012). Mental toughness among footballers: A case study. International Journal of Academic Research in Business and Social Sciences, 2, 639-658.

Omar-Fauzee, M. S., Yusof, A., \& Zizzi, S. (2009). College students' attitude towards the utilization of the sport recreation center (SRC). European Journal of Social Sciences, 7, 27-41.

Rattanakoses, R., Omar-Fauzee, M. S., \& Soh, K. G. (2009). Evaluating the relationship of imagery and self-confidence in female and male athletes. European Journal of Social Sciences, 10 (1), 129-142.

Sadeghi, H., Omar-Fauzee, M. S., Jamalis, M., Ab-Latiff, R., \& Cheric, M. C. (2010). The mental skills training of university soccer players. International Education Studies, 3, 81-90.

Sheard, M. (2010). Mental toughness: The mindset behind sporting achievement. London: Routledge.

Smith, R. E., \& Christensen, D. S. (1995). Psychological skills as predictors of performance and survival in professional baseball. Journal of Sport and Exercise Psychology, 17, 399-415.

Smith, R. E., Schultz, R. W., Smoll, F. L., \& Ptacek, J. T. (1995). Development and validation of a multidimensional measure of sport-specific psychological skills: The Athletic Coping Skills Inventory-28. Journal of Sport and Exercise Psychology, 17, 379-398.

Weinberg, R. S., \& Gould, D. (2011). Foundations of sport and exercise psychology (6th ed.). Champaign, IL: Human Kinetics. 